Title

4

5

6

7

\title{
Effects of mildly heated, slightly acidic electrolyzed water on the disinfection and physicochemical properties of sliced carrot
}

\author{
Authors \\ Shoji Koide ${ }^{\text {a,* }}$, Douglas Shitanda ${ }^{\text {a, b }}$, Mizuho Note ${ }^{a}$, Wei Cao ${ }^{\text {c }}$

\begin{abstract}
Affiliations
${ }^{a}$ Faculty of Agriculture, Iwate University, Morioka 020-8550, Japan

${ }^{\mathrm{b}}$ Faculty of Engineering, Jomo Kenyatta University of Agriculture and Technology, P.O. Box 62000-00200 Nairobi, Kenya

${ }^{\mathrm{c}}$ The key Laboratory of Bio-Environment Engineering, China Agricultural University, P.O. Box 67, Beijing 100083, China
\end{abstract}

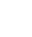

\begin{abstract}
The efficacy of mildly heated, slightly acidic electrolyzed water (mildly heated SlAEW) at $45^{\circ} \mathrm{C}$ for disinfection and maintenance of sliced carrot quality was studied. Mildly heated SlAEW (23 mg/L available chlorine, $\mathrm{pH}$ at 5.5) was used to treat the carrots, followed by

* Corresponding author. Tel.; +81-19-621-6182; fax: +81-19-621-6182.


rinsing with tap water (TW) for 2 min at $4{ }^{\circ} \mathrm{C}$, and its effectiveness as a disinfectant was evaluated. The physicochemical properties of the carrots were determined and a comparison was made between treatments with SIAEW at room temperature $\left(18^{\circ} \mathrm{C}\right)$, TW at $18^{\circ} \mathrm{C}$ and mildly heated TW at $45^{\circ} \mathrm{C}$. Results show that total aerobic bacteria, mold and yeast populations were significantly lower after mildly heated SIAEW treatment. Mildly heated SIAEW treatment reduced the total aerobic bacteria by $2.2 \log _{10} \mathrm{CFU} / \mathrm{g}$ and molds and yeasts by $>1.9 \log _{10} \mathrm{CFU} / \mathrm{g}$ compared with TW treatment. Color indices of hue and chroma of sample surfaces were not affected by mildly heated SlAEW treatment and there were insignificant differences in hardness or the ascorbic acid and $\beta$-carotene contents of sliced carrots. The use of mildly heated SlAEW is suggested as an effective disinfection method for fresh cut carrots with low available chlorine.

Keywords

Carrot; Disinfection; Mildly heated SlAEW; Quality; Slightly acidic electrolyzed water

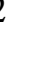

\section{Main text}

\section{Introduction}

There is high consumer demand for fresh fruit and vegetables that exhibit high quality and microbial safety. Thus, sanitization of fresh fruit and vegetables is desirable to control spoilage bacteria and fungi to extend shelf life and decontaminate pathogenic organisms for food safety (McKellar et al., 2004; Qiang, Demirkol, Ercal, \& Adams, 2005). The

\footnotetext{
* Corresponding author. Tel.; +81-19-621-6182; fax: +81-19-621-6182.
} 
disinfectants commonly studied and/or used in the food industry include ozone (either gaseous- or aqueous-phase), free chlorine $\left(\mathrm{HOCl} / \mathrm{OCl}^{-}\right)$and hydrogen peroxide. Chlorine disinfection has been extensively applied in the harvest and postharvest handling of fresh fruit and vegetables for many decades because it is effective, chemically stable, readily available, relatively inexpensive and easily applied. Although chlorine is the most commonly used sanitizer, it is inactivated by organic material and can lead to the formation of potentially carcinogenic and teratogenic trihalomethanes and haloacetic acids. Therefore, many alternative sanitation agents have been developed and their disinfection abilities evaluated for the food industry (Keskinen, Burkea, \& Annous, 2009).

Recently, a new concept involving chlorine water, named "acidic electrolyzed water" (AEW or AcEW) or "slightly acidic electrolyzed water" (SlAEW or SAEW), has been increasingly used for the disinfection of fresh vegetables and fruit because it is easy to produce continuously through electrolysis using commercial equipment. During the past decade, many reports have indicated that AEW could be used as a postharvest food disinfectant (Huang, Hung, Hsu, Huang, \& Hwang, 2008; Koseki, \& Itoh, 2000). At a pH of 5.0-6.5, the effective form of the chlorine in SlAEW is mainly hypochlorous acid ( $\mathrm{HOCl})$ (Okamoto et al., 2006). SlAEW has the advantage of possessing antimicrobial activity with low available chlorine (Koide, Takeda, Shi, Shono, \& Atungulu, 2009; Rahman, Ding, \& Oh, 2010), resulting in reduced corrosion of surfaces and minimization of the potential for damage to human health and the environment. Therefore, there is growing interest in new applications for the bactericidal activity of SlAEW in the food industry (Soli et al., 2010).

To date, it has been presumed that combining warm water treatment with chlorine would reduce the microbial load more effectively than using cold water (Delaquis, Stewart, Toivonen, \& Moyls, 1999). Koseki, Yoshida, Kamitani, Isobe, and Itoh (2004) indicated that a procedure for treating vegetables with mildly heated alkaline electrolyzed water $\left(50^{\circ} \mathrm{C}\right)$ for $5 \mathrm{~min}$ and

\footnotetext{
* Corresponding author. Tel.; +81-19-621-6182; fax: +81-19-621-6182.
} 
subsequent washing with chilled acidic electrolyzed water $\left(4^{\circ} \mathrm{C}\right)$ for a period of 1 or 5 min resulted in 3-4 $\log _{10} \mathrm{CFU} / \mathrm{g}$ reduction of pathogenic bacterial (Escherichia coli $\mathrm{O} 157: \mathrm{H} 7$ and Salmonella) counts on lettuce. Wei, Brandt, Wolf, and Hammes (2005) showed that an acidified warm water treatment at $50{ }^{\circ} \mathrm{C}$ and $\mathrm{pH} 4.93$ reduced the total bacteria by $2.3 \log _{10}$ CFU/g, and Enterobacteriaceae by $2.53 \log _{10} \mathrm{CFU} / \mathrm{g}$ on cut iceberg lettuce after washing. Recently, an evaluation has been carried out on SIAEW disinfection at different temperatures $\left(4,20\right.$ and $\left.45^{\circ} \mathrm{C}\right)$ for inactivation of Salmonella enteritidis on the surface of egg shells (Cao, Wei, Zheng, Shi, Wang, \& Li, 2009). However, no information is available on the efficacy of warm SlAEW on fruit and vegetables.

The objective of this study was to evaluate the efficacy of mildly heated SlAEW at $45^{\circ} \mathrm{C}$ in the disinfection of sliced carrots and the maintenance of physicochemical quality compared with SIAEW $\left(18^{\circ} \mathrm{C}\right)$ and tap water $(\mathrm{TW})\left(18\right.$ and $\left.45^{\circ} \mathrm{C}\right)$ treatments. The results will provide the basic information on both disinfection ability and maintenance of quality for fresh fruit and vegetables that is needed to improve the use of SlAEW in practice.

\section{Materials and methods}

\subsection{Sample preparation}

Carrots used in this study were purchased from a local supermarket in Morioka, Japan, and stored at $5^{\circ} \mathrm{C}$ in an incubator before the experiment. The central part of each carrot was cut into round slices in quarters with a width of about $5 \mathrm{~mm}$ before treatment.

\subsection{Disinfection treatment}

* Corresponding author. Tel.; +81-19-621-6182; fax: +81-19-621-6182.

E-mail address: shojides@iwate-u.ac.jp (S. Koide) 
SlAEW was prepared using a flow type electrolysis apparatus (Purester, Morinaga Engineering Co., Ltd., Japan), as described in a previous study (Koide et al., 2009), and TW was used as a control. Each solution of SIAEW and TW was stored in polypropylene containers $(220 \times 345 \times 135 \mathrm{~mm})$ and the temperature immediately controlled at 18 and $45^{\circ} \mathrm{C}$ in a water bath. Immersion of sliced carrots in $\mathrm{TW}$ at $18^{\circ} \mathrm{C}$ and $45^{\circ} \mathrm{C}$ and SIAEW solution at $18^{\circ} \mathrm{C}$ and $45^{\circ} \mathrm{C}$ are expressed as TW treatment, mildly heated TW treatment, SlAEW treatment and mildly heated SIAEW treatment, respectively. A $200 \mathrm{~g}$ sample of fresh sliced carrots was dipped into each solution for $10 \mathrm{~min}$ and then all samples were rinsed in cold TW at $4{ }^{\circ} \mathrm{C}$ stored in polypropylene containers $(220 \times 345 \times 135 \mathrm{~mm})$ for $2 \mathrm{~min}$.

The $\mathrm{pH}$ of each solution was measured with a pH meter (MP-220, Mettler, Germany) and the initial concentration of available chlorine in each solution at $18^{\circ} \mathrm{C}$ was determined by chlorine test kits (AQ-102, Shibata Co. Ltd., Japan). The pH values of TW and SlAEW were 7.0 \pm 0.1 and 5.5 \pm 0.1 , respectively. The values of available chlorine in TW and SlAEW were 0.4 and $23.0 \pm 1.2 \mathrm{mg} / \mathrm{L}$, respectively.

\subsection{Determination of physicochemical properties}

The physicochemical properties determined were the color, hardness, ascorbic acid content and $\beta$-carotene content of sliced carrots before and after treatment.

\subsubsection{Surface color}

The $L^{*}$ (lightness), $a^{*}$ (redness-greenness) and $b^{*}$ (yellowness-blueness) indices of the CIELAB colorimetric system were used to evaluate the color change of the sliced carrot samples. $L^{*}, a^{*}$ and $b^{*}$ were first measured using a colorimeter (Nippon Denshoku NF-333, Japan) at three different spots on the surface of at least six samples before and after each treatment.

* Corresponding author. Tel.; +81-19-621-6182; fax: +81-19-621-6182. 
Chroma $(C)$, Hue angle $\left(H^{o}\right)$ and the change in the surface color of the sample (total color difference, $\Delta E$ ), were calculated from the following formulae.

$$
C=\left(a^{* 2}+b^{* 2}\right)^{1 / 2}
$$

where, $L_{0}^{*}, a_{0} *$ and $b_{0} *$ were the initial colorimeter values of the sample.

\subsubsection{Hardness}

Hardness was measured using a hand-operated penetrometer (Ebara, KM Type, Japan). A $10 \mathrm{~mm}$ diameter cone probe with a height of $12 \mathrm{~mm}$ was pressed vertically against the surface of the sliced carrots and hardness recorded in $\mathrm{kg}$.

\subsubsection{Ascorbic acid content}

Ascorbic acid content in each sample was determined by a method described previously (Koide \& Shi, 2007; Takebe \& Yoneyama, 1995) with slight modification. The carrot sample was weighed, homogenized with $5 \%$ meta-phosphoric acid $\left(\mathrm{HPO}_{3}\right)$, and the exudate was immediately used for the determination of the ascorbic acid content using a reflection photometer (Merck, RQflex, Germany). The ascorbic acid values were expressed in $\mathrm{mg} / 100 \mathrm{~g}$ fresh weight.

\subsection{4. $\beta$-carotene content}

$\beta$-carotene content in each sample was determined using the method described by Nagata, Noguchi, Ito, Imanishi, and Sugiyama (2007). The carrot sample was weighed, homogenized with acetone, and the slurry filtered and centrifuged twice for $10 \mathrm{~min}$ at $12,500 \times \mathrm{g}$. The

* Corresponding author. Tel.; +81-19-621-6182; fax: +81-19-621-6182. 
resultant supernatant was used to measure absorbance at 443,492 and $505 \mathrm{~nm}$ by a spectrophotometer (Jasco V-530, Japan). The $\beta$-carotene content was calculated using following equation:

$$
\beta \text {-carotene }(\mathrm{mg} / \mathrm{L})=-1.488 A_{443}+4.844 A_{492}-2.352 A_{505}+0.098
$$

where $A_{443}, A_{492}$ and $A_{505}$ indicate absorbances at 443,492 and $505 \mathrm{~nm}$, respectively. $\beta$-carotene content was expressed in $\mathrm{mg} / 100 \mathrm{~g}$ fresh weight.

\subsection{Microbiological analysis}

To enumerate the microorganisms, $20 \mathrm{~g}$ of each fresh carrot sample was mixed with 180 $\mathrm{mL}$ of sterile $0.85 \%$ sodium chloride solution in a sterile polyethylene bag, and pummeled with a stomacher (Seward Stomacher 400, UK) for 2 min at high speed. The aliquot was used for various serial dilutions. The diluted samples were analyzed for the populations of total aerobic bacteria, molds and yeasts by using the method of Mise and Inoue (1996). Total aerobic bacteria were enumerated on an agar plate of the following composition $(\mathrm{g} / \mathrm{L})$ : Yeast extract (Difco Laboratories, USA), 2.5; tryptone (Difco Laboratories), 5.0; glucose (Wako, Japan), 1.0; agar (Difco Laboratories), 15.0. The plates were incubated at $35^{\circ} \mathrm{C}$ for $48 \mathrm{~h}$ and the colonies counted. Molds and yeasts were enumerated on potato dextrose agar (PDA) plates with $0.1 \mathrm{~g} / \mathrm{L}$ chloramphenicol (Nissui, Japan). The plates were incubated at $25^{\circ} \mathrm{C}$ for 5 days and the colonies of molds and yeasts were counted and expressed as $\log _{10} \mathrm{CFU} / \mathrm{g}$.

\subsection{Statistical analysis}

All experiments were carried out at least five times each in duplicates or triplicates. Data were expressed as the mean \pm standard error. The results were statistically evaluated using a 
Tukey's test and the significance of difference was defined as $P<0.05$.

\section{Results and discussion}

\subsection{Changes in microbial population}

The microbial populations of total aerobic bacteria in carrot samples after treatment with TW, mildly heated TW, SIAEW and mildly heated SIAEW are shown in Table 1. These show that the total aerobic bacteria population was highest after TW treatment, followed by SlAEW treatment and mildly heated TW treatment, while the lowest population occurred after mildly heated SlAEW treatment. Among the treatments, there was significant difference $(P<0.05)$ between mildly heated SIAEW treatment and all the other treatments. It was found that mildly heated SlAEW reduced the total aerobic bacterial population significantly $(P<0.05)$ relative to TW and SlAEW treatments, by about 2.2 and $1.6 \log _{10} \mathrm{CFU} / \mathrm{g}$, respectively. The mold and yeast populations showed similar results to those of total aerobic bacteria. It was found that mildly heated SIAEW treatment reduced the populations of molds and yeasts significantly $(P$ $<0.05$ ) relative to TW and SIAEW treatments, by $>1.9$ and $>1.3 \log _{10}$ CFU/g, respectively. The reduction rate in total aerobic bacteria between SIAEW and TW treatments agrees with previous reports on disinfection test using electrolyzed water. Izumi (1999) showed that the total microbial count of carrot slices $(35-40 \mathrm{~mm}$ diameter and $3 \mathrm{~mm}$ thick) treated with electrolyzed water ( $\mathrm{pH}$ 6.8) containing $50 \mathrm{mg} / \mathrm{L}$ chlorine for $3 \mathrm{~min}$, followed by rinsing with TW for $1 \mathrm{~min}$, was reduced by $1.1 \log _{10} \mathrm{CFU} / \mathrm{g}$ on the surface and $1.1 \log _{10} \mathrm{CFU} / \mathrm{g}$ in the macerate of the sample, compared with TW treatment. Koseki \& Itoh (2000) reported that total microbial count of thin strips of carrot (2-3 mm thick) treated with AEW (pH 2.4) containing $45.3 \mathrm{mg} / \mathrm{L}$ chlorine for 5 min was reduced by $1.4 \log _{10} \mathrm{CFU} / \mathrm{g}$, compared with TW

\footnotetext{
* Corresponding author. Tel.; +81-19-621-6182; fax: +81-19-621-6182.
} 
treatment. In this study, reduction in the total aerobic bacteria in the carrot sample (with a width of about $5 \mathrm{~mm}$ ) between SlAEW treatment $\left(23 \mathrm{mg} / \mathrm{L}\right.$ available chlorine, $\left.18^{\circ} \mathrm{C}\right)$ and $\mathrm{TW}$ treatments $\left(18^{\circ} \mathrm{C}\right)$ was as low as $0.6 \log _{10} \mathrm{CFU} / \mathrm{g}$. However, by heating the SlAEW, the reduction in the total aerobic bacteria in the carrot samples was higher compared with TW treatment. Because treatment with mildly heated SIAEW showed an effective disinfection effect higher than that with SIAEW, it would be advantageous to use mildly heated SIAEW.

The ratios of molds present on PDA plates were 1.0, 0.6, 0.6 and $0.0 \%$ in the populations of molds and yeasts for TW, mildly heated TW, SIAEW and mildly heated SIAEW, respectively (Table 1). This is the first study on the fungicidal efficacy of mildly heated SlAEW on fresh cut vegetables. Buck, van Iersel, Oetting, and Hung (2002) treated 22 fungal species with AEW in vitro and reported that germination of all 22 fungal species was significantly reduced or prevented. They found that all relatively thin-walled species (e.g. Botrytis, Monilinia) were killed by incubation times of $30 \mathrm{~s}$ or less. Al-Haq, Seo, Oshita, and Kawagoe (2002) reported that AEW was an effective surface sanitizer for suppressing fruit rot on pears caused by Botryosphaeria berengeriana. Furthermore, it was reported that hot water and chlorine seed treatments could eradicate or significantly reduce the incidence of a number of seedborne molds without adversely affecting seed quality (du Toit \& Hernandez-Perez, 2005).

Considering the above matter, mildly heated SlAEW treatment can also be applied for fungicidal control on food postharvest. However, further studies are necessary.

\subsection{Changes in physicochemical properties}

Changes in the surface color of carrot samples before and after treatments are shown in Table 2. Because untreated samples that have not been immersed in either tap water or SlAEW tend to change color slightly after immersion, we decided that a TW sample was the

\footnotetext{
* Corresponding author. Tel.; +81-19-621-6182; fax: +81-19-621-6182.
}

E-mail address: shojides@iwate-u.ac.jp (S. Koide) 
best to use for the comparison of color changes among treated samples. As shown in Table 2, there is no significant difference $(P<0.05)$ in hue, which correlates with visual appearance, between samples treated with TW, mildly heated TW, SIAEW and mildly heated SlAEW. Moreover, there are no significant differences $(P<0.05)$ in chroma between treated samples. There was a significant difference in total color difference $(\Delta E)$ between samples treated with TW and mildly heated SlAEW, compared with untreated samples. However, the difference in $\Delta E$ of samples treated with TW and mildly heated SlAEW indicated low value at 1.3 , and it could be considered as unremarkable change. The obtained $\Delta E$ values in this study were almost same values as described in a previous study (Koseki \& Itoh, 2001). It was reported that compared with the untreated sample, the $\Delta E$ values in strips of carrot 2-3 $\mathrm{mm}$ in width immersed for $10 \mathrm{~min}$ in $\mathrm{AEW}$ (42.3 mg/L available chlorine, $\mathrm{pH}$ at 2.5), $\mathrm{NaOCl}$ solution (150 $\mathrm{mg} / \mathrm{L}$ available chlorine, $\mathrm{pH}$ at 9.3$)$, and tap water $(0.3 \mathrm{mg} / \mathrm{L}$ available chlorine, $\mathrm{pH}$ at 7.0$)$ were 4.4, 4.2 and 3.9 respectively. Furthermore, Izumi (1999) found that electrolyzed water (pH 6.8) containing $50 \mathrm{mg} / \mathrm{L}$ chlorine did not affect the surface color in hue in carrot slices (35-40 mm diameter and $3 \mathrm{~mm}$ thick) compared with samples rinsed in tap water for $4 \mathrm{~min}$. The above reports and our results, suggest that surface color changes of sliced carrots immersed in mildly heated SIAEW for 10 min followed by rinsing with tap water for 2 min at $4^{\circ} \mathrm{C}$ is acceptable and practical compared with TW treatment or other types of electrolyzed water.

Table 3 shows the changes in hardness, ascorbic acid content and $\beta$-carotene content of carrot samples before and after treatment. There were no significant differences in hardness between untreated and treated samples. Usually, the Young's modulus of fresh agricultural products increases with decreasing temperature (Murata \& Koide, 1994). In this study, all treated samples were subjected to disinfection treatments for 10 min followed by rinsing and cooling with cold TW at $4^{\circ} \mathrm{C}$ for 2 min. Because samples subjected to mildly heated TW and 
mildly heated SIAEW followed by no rinse treatment tended to have a slight decrease in hardness, rinsing samples with cold water after disinfection treatment with mildly heated SlAEW would be a viable method for maintaining hardness quality.

Compared with untreated samples, reductions in the ascorbic acid content were 12.2, 16.5, 10.8 and $18.0 \%$ for TW, mildly heated TW, SIAEW and mildly heated SlAEW treatments, respectively. This result agrees with the results using other types of electrolyzed water and samples (Koseki \& Itoh, 2001; Vandekinderen et al., 2009). Koseki and Itoh (2001) reported that cut vegetables subjected to immersion in AEW (42.3 mg/L available chlorine, $\mathrm{pH}$ at 2.5), $\mathrm{NaOCl}$ solution $(150 \mathrm{mg} / \mathrm{L}$ available chlorine, $\mathrm{pH}$ at 9.3$)$ or tap water $(0.3 \mathrm{mg} / \mathrm{L}$ available chlorine, $\mathrm{pH}$ at 7.0 ) for $10 \mathrm{~min}$ showed $15-20 \%$ reductions in ascorbic acid content for cut cabbage, $10-15 \%$ reductions for cut lettuce and 30-35\% reductions for cut cucumber. Ascorbic acid is a water soluble compound and its concentration in cut vegetables after washing tends to decrease easily due to its leaching and degradation from the cut surface. However, the loss in quality of cut vegetables treated with strongly acidic electrolyzed water is said to be equivalent $(P<0.05)$ to treatment with $\mathrm{NaOCl}$ solution and tap water (Koseki \& Itoh, 2001). Similar to previous studies, the experimental results show that the reduction of ascorbic acid content for the mildly heated SIAEW treatment, compared with TW and mildly heated TW treatment, was as low as 6.6 and $1.7 \%$, respectively, and there was no significant difference between untreated and treated samples. Thus, mildly heated SlAEW treatment did not cause a significant additional decrease in ascorbic acid content, similar to other types of electrolyzed water.

For $\beta$-carotene content, there was no significant difference between the untreated and treated samples. Compared with untreated samples, the $\beta$-carotene contents for TW, mildly heated TW, SlAEW and mildly heated SlAEW treatment, were reduced by 8.3, 11.3, 11.3 and $13.6 \%$, respectively. Results also indicated that the reduction in $\beta$-carotene content for mildly

* Corresponding author. Tel.; +81-19-621-6182; fax: +81-19-621-6182. 
heated SlAEW treatment compared with TW and mildly heated TW treatment were as low as 5.8 and $2.6 \%$, respectively. This trend is similar to that described in a previous report (Koseki $\&$ Itoh, 2001) in which $\beta$-carotene content in thin strips of carrot 2-3 $\mathrm{mm}$ in width immersed in $\mathrm{AEW}$ (42.3 mg/L available chlorine, $\mathrm{pH}$ at 2.5) for $10 \mathrm{~min}$ was reduced by $30 \%$, but there was no significant difference between $\mathrm{NaOCl}$ solution $(150 \mathrm{mg} / \mathrm{L}$ available chlorine, $\mathrm{pH}$ at 9.3) and tap water (0.3 mg/L available chlorine, $\mathrm{pH}$ at 7.0$)$. However, changes in the surface color of carrot samples were unremarkable as stated above. There are two possible reasons for this trend: first, because the color measurement was conducted immediately after disinfection, while $\beta$-carotene content were analyzed a few minutes after disinfection, so the content may have been more than the amount recorded at that time; second, due to the existence of other pigments such as carotenoids ( $\alpha$-carotene and lycopene, etc.) and xanthophylls in carrots (Koch, \& Goldman, 2005). The measured $\beta$-carotene content, therefore, might not exactly correlate with the color values, and further study is required to investigate changes in $\beta$-carotene and other pigments immediately after immersion in SlAEW. The mechanism of decomposition of $\beta$-carotene, influenced by hypochlorous acid $(\mathrm{HOCl})$ in SIAEW and temperature, is not clear but $\beta$-carotene is mainly associated with membrane protein complexes in the chloroplast or the chromoplast (Kalt, 2005). Thus, it can be said that thickness and contact area of the sample are good nutrient retention indicators during disinfection treatments.

Results of physicochemical property measurements on retention of color, hardness, ascorbic acid content and $\beta$-carotene content show that samples treated with mildly heated SIAEW would be suitable for the market. However, physicochemical data were taken only on day 0 . The optimum disinfection time and the effects of concentration of available chlorine and temperature of the SIAEW on microbial load and quality during storage is not known and warrants further studies.

\footnotetext{
* Corresponding author. Tel.; +81-19-621-6182; fax: +81-19-621-6182.
} 
In conclusion, mildly heated slightly acidic electrolyzed water at $45^{\circ} \mathrm{C}(23 \mathrm{mg} / \mathrm{L}$ available chlorine, $\mathrm{pH}$ at 5.5) was found to be effective disinfectant and maintenance method for fresh sliced carrot. The method can be adopted commercially to ensure the safety of consumers and the environment, high product quality and low disinfection costs.

\section{Acknowledgments}

The authors are grateful to Ms. Ai Kato and Ms. Moe Ito for their technical assistance during the experiments.

\section{References}

Al-Haq, M.I., Seo, Y., Oshita, S., \& Kawagoe, Y. (2002). Disinfection effects of electrolyzed oxidizing water on suppressing fruit rot of pear caused by Botryosphaeria berengeriana. Food Research International, 35, 657-664.

Buck, J.W., van Iersel, M.W., Oetting, R.D., \& Hung, Y.C. (2002). In vitro fungicidal activity of acidic electrolyed oxidizing water. Plant Disease, 20, 278-281.

Cao, W., Wei, Z., Zheng, Z., Shi, X., Wang, C.Y., \& Li, B.M. (2009). Efficiency of slightly acidic electrolyzed water for inactivation of Salmonella enteritidis and its contaminated shell eggs. International Journal of Food Microbiology, 130, 88-93.

Delaquis, P. J., Stewart, S., Toivonen, P. M. A., \& Moyls, A. L. (1999). Effect of warm, chlorinated water on the microbial flora of shredded iceberg lettuce. Food Research International, 32, 7-14.

du Toit, L.J., \& Hernandez-Perez, P. (2005). Efficacy of hot water and chlorine for eradication of Cladosporium variabile, Stemphylium botryosum, and Verticillium dahliae from

* Corresponding author. Tel.; +81-19-621-6182; fax: +81-19-621-6182. 
Spinach Seed. Plant Disease, 89, 1305-1312.

Huang, Y.R., Hung, Y.C., Hsu, S.Y., Huang, Y.W., \& Hwang, D.F. (2008). Application of electrolyzed water in the food industry. Food Control, 19, 329-345.

Izumi, H. (1999). Electrolyzed water as a disinfectant for fresh-cut vegetables. Journal of Food Science, 64, 536-539.

Kalt, W. (2005). Effects of production and processing factors on major fruit and vegetable antioxidants. Journal of Food Science, 70, R11-R19.

Keskinen, L.A., Burkea, A., \& Annous, B.A. (2009). Efficacy of chlorine, acidic electrolyzed water and aqueous chlorine dioxide solutions to decontaminate Escherichia coli O157:H7 from lettuce leaves. International Journal of Food Microbiology, 132, 134-140.

Koch, T.C., \& Goldman, I.L. (2005). Relationship of carotenoids and tocopherols in a sample of carrot root-color accessions and carrot germplasm carrying $R p$ and $r p$ alleles. Journal of Agricultural and Food Chemistry, 53, 325-331.

Koide, S., \& Shi, J. (2007). Microbial and quality evaluation of green peppers stored in biodegradable film packaging. Food Control, 18, 1121-1125.

Koide, S., Takeda, J., Shi, J., Shono, H., Atungulu, G..G.. (2009). Disinfection efficacy of slightly acidic electrolyzed water on fresh cut cabbage. Food Control, 20, 294-297.

Koseki, S., \& Itoh, K. (2000). Effect of acidic electrolyzed water on the microbial counts in shredded vegetables. Journal of the Japanese Society for Food Science and Technology, 47, 722-726. (in Japanese)

Koseki, S., \& Itoh, K. (2001). The effect of acidic electrolyzed water on the quality of cut vegetables. Journal of the Japanese Society for Food Science and Technology, 48, 365-369. (in Japanese)

Koseki, S., Yoshida, K., Kamitani, Y., Isobe, S., \& Itoh, K. (2004). Effect of mild heat pre-treatment with alkaline electrolyzed water on the efficacy of acidic electrolyzed water

* Corresponding author. Tel.; +81-19-621-6182; fax: +81-19-621-6182. 
against Escherichia coli O157:H7 and Salmonella on Lettuce. Food Microbiology, 21, $559-566$.

352

353

354

355

356

357

358

McKellar, R.C., Odumeru, J., Zhou, T., Harrison, A., Mercer, D.G.., Young, J.C., Lu, X., Boulter, J., Piyasena, P., \& Karr, S. (2004). Influence of a commercial warm chlorinated water treatment and packaging on the shelf-life of ready-to-use lettuce. Food Research International, 37, 343-354.

Mise, K., \& Inoue, F. (1996). Manual of Inspection of Microorganisms in Foods, Tokyo: Ko-dansha. (in Japanese).

Murata, S., \& Koide, S. (1994). Temperature dependency of Young's modulus and Poisson's ratio of agricultural and food materials: Measuring under both ends fixed boundary condition. Journal of Japanese Society of Agricultural Machinery, 56(6), 41-49. (in Japanese)

Nagata, M., Noguchi, Y., Ito, H., Imanishi, S., \& Sugiyama, K. (2007). A Simple spectrophotometric method for the estimation of $\alpha$-carotene, $\beta$-carotene and lycopene concentrations in carrot acetone extracts. Journal of the Japanese Society for Food Science and Technology, 54, 351-355. (in Japanese)

Okamoto, M., Komagata, Y., Okuda, S., Nishimoto, Y., Kamoshida, M., Nakamura, T., \& Komiyama, K. (2006). Microbicidal effect slightly acidic electrolyzed water. Bokin Bobai, 34(1), 3-10. (in Japanese)

Qiang, Z., Demirkol, O., Ercal, N., \& Adams, C. (2005). Impact of food disinfection on beneficial biothiol contents in vegetables. Journal of Agricultural and Food Chemistry, $53,9830-9840$.

Rahman, S.M.E., Ding, T., \& Oh, D.H. (2010). Inactivation effect of newly developed low concentration electrolyzed water and other sanitizers against microorganisms on spinach. Food Control, 21, 1383-1387.

* Corresponding author. Tel.; +81-19-621-6182; fax: +81-19-621-6182.

E-mail address: shojides@iwate-u.ac.jp (S. Koide) 
Soli, K.W., Yoshizumi, A., Motomatsu, A., Yamakawa, M., Yamasaki, M., Mishima, T., Miyaji, N., Honjoh, K., \& Miyamoto, T. (2010). Decontamination of fresh produce by the use of slightly acidic hypochlorous water following pretreatment with sucrose fatty acid ester under microbubble generation. Food Control, 21, 1240-1244.

Takebe, M., \& Yoneyama T. (1995). An analysis of nitrate and ascorbic acid in crop exudates using a simple reflection photometer system. Soil Science and Plant Nutrition, 66, $155-158$.

Vandekinderen, I., Van Camp, J., De Meulenaer, B., Veramme, K., Bernaert, N., Denon, Q., Ragaert, P., \& Devlieghere, F. (2009). Moderate and high doses of sodium hypochlorite, neutral electrolyzed oxidizing water, peroxyacetic acid, and gaseous chlorine dioxide did not affect the nutritional and sensory qualities of fresh-cut iceberg lettuce (Lactuca sativa var. capitata L.) after washing. Journal of Agricultural and Food Chemistry, 57, 4195-4203.

Wei, H., Brandt, M.J., Wolf, G.., \& Hammes, W.P. (2005). Optimization of acidified warm water treatment to improve the microbiological status and sensory quality of iceberg lettuce. European Food Research and Technology, 220, 168-175.

* Corresponding author. Tel.; +81-19-621-6182; fax: +81-19-621-6182. 
2 Table 1 Microbial populations of total aerobic bacteria, and molds and yeasts of sliced

3 carrots treated for 10 min with tap water (TW) at $18^{\circ} \mathrm{C}$, mildly heated $\mathrm{TW}$ at $45^{\circ} \mathrm{C}$,

4 slightly acidic electrolyzed water (S1AEW) at $18^{\circ} \mathrm{C}$ and mildly heated S1AEW at $45^{\circ} \mathrm{C}$,

5 followed by immersion in $\mathrm{TW}$ at $4^{\circ} \mathrm{C}$ for $2 \mathrm{~min}$.

\begin{tabular}{|c|c|c|c|c|}
\hline Treatment & Temperature & $\begin{array}{c}\text { Total aerobic } \\
\text { bacteria } \\
\log _{10} \mathrm{CFU} / \mathrm{g}\end{array}$ & $\begin{array}{l}\text { Molds and yeasts } \\
\qquad \log _{10} \mathrm{CFU} / \mathrm{g}\end{array}$ & $\begin{array}{c}\text { Presence ratio } \\
\text { of molds }{ }^{\mathrm{A}} \\
\%\end{array}$ \\
\hline TW & 18 & $3.5 \pm 0.7 \mathrm{a}^{\mathrm{B}}$ & $0.7 \mathrm{a}$ & 1.0 \\
\hline TW & 45 & $2.6 \pm 0.7 b$ & $2.3 \pm 0.7 b$ & 0.6 \\
\hline SlAEW & 18 & $2.9 \pm 0.4 \mathrm{~b}$ & $2.6 \pm 0.5 \mathrm{ab}$ & 0.6 \\
\hline SlAEW & 45 & $1.3 \pm 0.3 \mathrm{c}$ & $<1.3 \mathrm{c}$ & 0.0 \\
\hline
\end{tabular}

${ }^{\mathrm{A}}$ Average presence ratio of molds for all samples in PDA plates for the enumeration of

7 molds and yeasts.

$8{ }^{\text {B }}$ Mean values \pm standard deviation. Values followed by different letters in the same

9 row indicate significant differences. 
Table 2 Changes in surface color of carrot samples

\begin{tabular}{|c|c|c|c|c|c|c|c|}
\hline Treatment & $\begin{array}{c}\text { Temperature } \\
\left({ }^{\circ} \mathrm{C}\right)\end{array}$ & $L^{*}$ & $a^{*}$ & $b^{*}$ & Hue & Chroma & $\begin{array}{l}\text { Total color } \\
\text { difference }\end{array}$ \\
\hline untreated & - & $58.5 \pm 1.4 \mathrm{ab}^{\mathrm{A}}$ & $27.5 \pm 2.6 \mathrm{a}$ & $46.2 \pm 2.7 \mathrm{c}$ & $59.1 \pm 1.5 \mathrm{a}$ & $54.1 \pm 3.6 \mathrm{a}$ & - \\
\hline TW & 18 & $57.9 \pm 1.6 b$ & $27.9 \pm 2.3 \mathrm{a}$ & $48.6 \pm 1.7 \mathrm{ab}$ & $60.3 \pm 1.9 \mathrm{a}$ & $56.5 \pm 1.9 \mathrm{a}$ & $4.0 \pm 0.9 \mathrm{a}$ \\
\hline TW & 45 & $59.9 \pm 0.9 \mathrm{a}$ & $28.6 \pm 1.9 \mathrm{a}$ & $48.8 \pm 2.2 \mathrm{a}$ & $59.8 \pm 0.9 \mathrm{a}$ & $56.7 \pm 2.7 \mathrm{a}$ & $4.0 \pm 1.6 \mathrm{a}$ \\
\hline SIAEW & 18 & $59.9 \pm 1.2 \mathrm{a}$ & $27.3 \pm 0.9 \mathrm{a}$ & $46.8 \pm 1.1 \mathrm{bc}$ & $59.8 \pm 0.9 \mathrm{a}$ & $54.1 \pm 1.2 \mathrm{a}$ & $2.1 \pm 0.8 b$ \\
\hline SIAEW & 45 & $58.4 \pm 1.4 \mathrm{ab}$ & $28.3 \pm 1.9 \mathrm{a}$ & $47.7 \pm 1.2 \mathrm{abc}$ & $59.4 \pm 1.4 \mathrm{a}$ & $55.5 \pm 1.8 \mathrm{a}$ & $2.7 \pm 1.1 \mathrm{~b}$ \\
\hline
\end{tabular}

${ }_{\mathrm{A}}$ Mean values \pm standard deviation. Values followed by different letters in the same row indicate significant differences. 
Table 3 Changes in hardness, ascorbic acid content and $\beta$-carotene content of carrot samples

\begin{tabular}{lcccc}
\hline Treatment & $\begin{array}{c}\text { Temperature } \\
\left({ }^{\circ} \mathrm{C}\right)\end{array}$ & $\begin{array}{c}\text { Hardness } \\
(\mathrm{kg})\end{array}$ & $\begin{array}{c}\text { Ascorbic acid content } \\
\left.(\mathrm{mg} / 100 \mathrm{~g}-\mathrm{FW})^{\mathrm{A}}\right)\end{array}$ & $\begin{array}{c}\beta \text {-carotene content } \\
(\mathrm{mg} / 100 \mathrm{~g}-\mathrm{FW})\end{array}$ \\
\hline untreated & - & $3.1 \pm 0.2 \mathrm{a}^{\mathrm{B}}$ & $13.9 \pm 3.6 \mathrm{a}$ & $3.01 \pm 0.46 \mathrm{a}$ \\
TW & 18 & $3.0 \pm 0.2 \mathrm{a}$ & $12.2 \pm 4.0 \mathrm{a}$ & $2.76 \pm 0.81 \mathrm{a}$ \\
TW & 45 & $3.0 \pm 0.1 \mathrm{a}$ & $11.6 \pm 1.5 \mathrm{a}$ & $2.67 \pm 0.34 \mathrm{a}$ \\
SlAEW & 18 & $3.0 \pm 0.2 \mathrm{a}$ & $12.4 \pm 2.7 \mathrm{a}$ & $2.67 \pm 1.05 \mathrm{a}$ \\
SlAEW & 45 & $3.0 \pm 0.2 \mathrm{a}$ & $11.4 \pm 2.2 \mathrm{a}$ & $2.60 \pm 0.46 \mathrm{a}$ \\
\hline
\end{tabular}

\footnotetext{
${ }^{\mathrm{A}} \mathrm{FW}$ means fresh weight.

${ }^{B}$ Mean values \pm standard deviation. Values followed by different letters in the same row indicate significant differences.
} 